\title{
UJI TOKSISITAS DAN IDENTIFIKASI AWAL GOLONGAN SENYAWA AKTIF EKSTRAK ETANOL DAN N-HEKSANA TERIPANG PASIR (Holothuria scabra) KERING PANTAI KENJERAN SURABAYA
}

\author{
Nurul Inayah, Rachmawati Ningsih, Tri Kustono Adi \\ Jurusan Kimia, Fakultas Sains dan Teknologi, UIN Maulana Malik Ibrahim Malang
}

\begin{abstract}
Sea cucumber (H.Scabra) is a species of marine biota providing high economical and medical values. It has been hundreds years consumed for drug to cure various diseases in China. The aim of this research was to determine the level of the toxicity against brine shrimp larvae A.salina Leach in each dried sea cucumber (H.scabra) extract collected from Kenjeran Coast, Surabaya. The information would be beneficial for anticancer drug discovery .

The research was conducted by extracting samples using both ethanol and n-hexane solvents. The concentrated extract obtained then were used for the toxicity test against brine shrimp larvae of A.salina Leach (BSLT). The mortality data of A.salina Leach was analysed using probit analysis to determine the value of $\mathrm{LC}_{50}$ on each extract. The phytochemical assay and thin layer chromatography (TLC) was also apllied for both extracts.

The result showed that both ethanol and $n$-hexane exctracts performed toxicity level against brine shrimp larvae of A.salina Leach with $\mathrm{LC}_{50}$ less than 1000 ppm. The $\mathrm{n}$-hexane extract indicated $\mathrm{LC}_{50}$ of 189.093 ppm, higher than the ethanol extract, $286.031 \mathrm{ppm}$. The presence of steroids were detected in both extract whilst the alkaloids were only detected in the ethanol extract. Further separation of the $\mathrm{n}$-hexane exctrat using TLC in n-hexane; ethyl acetate;amonia (66:33:0.8) yielded 5 spots with the $\mathrm{Rf}$ of $0.3 ; 0.44 ; 0.54 ; 0.72$ and 0.78 , respectively.
\end{abstract}

Keywords : sea cucumber (holothuria scabra), artemia salina leach, toxicity test, phytochemical test

\section{ABSTRAK}

Teripang pasir (H.Scabra) merupakan salah satu jenis biota laut yang memiliki nilai ekonomis tinggi. Sudah ratusan tahun Cina menggunakan teripang pasir sebagai obat yang mampu menyembuhkan berbagai penyakit. Tujuan dari penelitian ini adalah untuk mengetahui tingkat toksisitas masing-masing ekstrak teripang pasir (H.scabra) dari pantai Kenjeran terhadap larva udang A.Salina Leach dan Untuk mengetahui kandungan senyawa aktif yang terkandung dalam ekstrak teripang pasir (H.scabra) dari pantai Kenjeran yang memiliki potensi bioaktifitas paling optimal.

Penelitian ini dilakukan dengan mengekstraksi sampel dengan pelarut etanol dan n-heksana. Ekstrak pekat yang diperoleh digunakan untuk uji toksisitas terhadap larva udang A.salina Leach (BSLT) dan uji fitokimia dengan reagen. Ekstrak yang memiliki toksisitas paling tinggi dilanjutkan dengan kromatografi lapis tipis eluen n-heksana:etit asetat:amoniak (66:33:0,8). Data kematian A.salina Leach dianalisis dengan analisis probit untuk mengetahui nilai $\mathrm{LC}_{50}$ pada masing-masing ekstrak.

Hasil dari penelitian ini menunjukkan bahwa masing-masing ekstrak teripang pasir (H.scabra) memiliki tingkat toksisitas terhadap larva udang A.salina Leach, ditunjukkan dengan nilai $\mathrm{LC}_{50}$ kurang dari 1000 ppm. Nilai keaktifan tertinggi diperoleh ekstrak n-heksana dengan nilai $\mathrm{LC}_{50}$ sebesar 189,093 ppm dan 286,031 ppm untuk ekstrak etanol. Kandungan senyawa aktif hasil uji reagen menunjukkan adanya potensi bioaktivitas dalam ekstrak teripang pasir (H.scabra) yaitu adanya golongan senyawa alkaloid (dalam ekstrak etanol) dan steroid (dalam ekstrak etanol dan n-heksana). Hasil KLT diperoleh 5 noda dengan nilai $\mathrm{Rf}=$ 0,$3 ; 0,44 ; 0,54 ; 0,72 ; 0,78$.

Kata kunci : teripang pasir(holothuria scabra), artemia salina leach, uji toksisitas, uji fitokimia. 


\section{PENDAHULUAN}

Indonesia merupakan negara kepulauan terbesar yang memiliki 17.504 pulau dan garis pantai lebih dari 81.000 $\mathrm{Km}^{2}$ dengan luas perairan laut sekitar 5,8 juta $\mathrm{Km}^{2}$ (Reina, 2004). Hal ini juga berimplikasi pada kepemilikan sumber daya laut Indonesia yang melimpah yang dapat dimanfaatkan untuk kehidupan. Pemanfaatan biota laut saat ini bukan hanya sekedar konsumtif saja, tetapi mengarah kepada penelitian yang lebih lanjut seperti obat-obatan dalam dunia medis yang tujuannya untuk mengangkat nilai ekonomi biota laut.

Salah satu potensi biota laut adalah teripang dengan nama lain teat fish, sea cucumber, dan ginseng laut. Teripang merupakan salah satu anggota hewan berkulit duri (Echinodermata), yang memiliki tubuh lunak, berdaging, dan berbentuk silindris memanjang (Martoyo, dkk., 2006). Teripang dapat ditemukan hampir diseluruh perairan, mulai dari daerah pasang surut yang dangkal sampai perairan yang lebih dalam. Teripang lebih menyukai perairan yang jernih dan airnya relatif tenang. Umumnya masing-masing jenis memiliki habitat yang spesifik. Misalnya teripang putih banyak ditemukan di daerah yang berpasir atau pasir bercampur lumpur pada kedalaman 1-40 m, penyebarang teripang di Indonesia sangat luas. Beberapa daerah penyebaran antara lain meliputi perairan pantai Madura, Jawa timur, Bali, Sumba, Lombok, Aceh, Bengkulu, Bangka, Riau dan sekitarnya, Belitung, Kalimantan, Sulawesi, Maluku, Timor, dan kepulauan seribu (Martoyo, 2006).

Teripang umumnya menempati ekosistem terumbu karang dengan perairan yang jernih, bebas dari polusi, air relatif tenang dengan mutu air cukup baik. Habitat yang ideal bagi teripang adalah air laut dengan salinitas 29-33 \%o yang memiliki kisaran pH 6,5-8,5, kecerahan air 50-150 $\mathrm{cm}$, kandungan oksigen terlarut 4-8 ppm dan suhu air laut $20-25^{\circ} \mathrm{C}$ (Wibowo dkk, 1997).
Menurut Matraga (2005) teripang sudah ratusan tahun digunakan sebagai obat-obatan di Cina. Menurut Wibowo dkk, (1997) teripang mengandung bahan bioaktif (antioksidan) yang berfungsi mengurangi kerusakan sel jaringan tubuh. Hasil penelitian Kaswandi dkk, (2000) menunjukkan bahwa ekstraksi komponen antibakteri dari teripang (H.acabunda) cukup efektif menghambat pertumbuhan bakteri Escherichia coli, Vibrio amsela. Ekstrak teripang juga menunjukkan aktifitas antiprotozoa dan menghambat sel tumor. Serta juga sebagai penyembuh luka dan antithrombotic yaitu untuk mengurangi pembekuan darah didalam saluran darah sehingga dapat mengurangi resiko penyakit stroke dan jantung (Farouk et al., 2007). Bagian hewan yang digunakan mencakup seluruhnya.

Jenis teripang yang paling banyak ditemukan di Indonesia adalah teripang pasir (Holothuria scabra) dengan tingkat penyebaran mencapai 38,86 \%. Penelitian ilmiah mengenai teripang pasir (H.scabra) khususnya teripang dari pantai Kenjeran Surabaya belum dilakukan secara meluas, sehingga dalam penelitian ini dilakukan pengujian awal untuk mengetahui adanya potensi bioaktivitas dan kandungan kimianya melalui uji senyawa aktif. Pelarut yang digunakan pada proses ekstraksi dalam penelitian ini yaitu etanol dan nheksana. Pelarut-pelarut tersebut memiliki titik didih yang cukup rendah agar pelarut dapat mudah diuapkan tanpa menggunakan suhu yang tinggi, bersifat inert, dapat melarutkan senyawaan yang sesuai dengan cukup cepat serta memiliki harga yang terjangkau. Titik didih pelarut n-heksana dan etanol, berturut-turut yaitu $68,7{ }^{\circ} \mathrm{C}$ dan 78,3 ${ }^{\circ} \mathrm{C}$ (Sudarmadji dkk., 2003).

\section{$\mathrm{LC}_{50}$ (Lethal Concentration-50)} adalah kadar atau konsentrasi suatu zat, yang dinyatakan dalam miligram bahan kimia per meter kubik media uji (part per million/ ppm), yang dapat menyebabkan 50 $\%$ kematian pada binatang percobaan dari suatu kelompok spesies setelah binatang 
percobaan tersebut terpapar dalam waktu tertentu (Cahyono, 2004).

Brine shrimp lethality test (BSLT) merupakan pengujian senyawa secara umum yang dapat mendeteksi beberapa bioaktivitas dalam suatu ekstrak. Beberapa kelebihan dari uji bioaktivitas dengan BSLT menggunakan larva udang Artemia salina adalah cepat waktu ujinya, sederhana (tanpa teknik aseptik), murah (tidak perlu serum hewan), jumlah organisme banyak, memenuhi kebutuhan validasi statistik dengan sedikit sampel (Meyer et a.l, 1982).

Artemia salina sering digunakan sebagai hewan uji toksisitas. Telur A. salina dapat bertahan dalam kondisi kering dan dapat disimpan cukup lama. Telur ini bila diberi air laut pada suhu $23^{\circ} \mathrm{C}$ maka ia akan menetas dalam 1-2 hari dan dapat langsung digunakan dalam uji toksisitas. A. salina diperdagangkan dalam bentuk telur istirahat yang disebut kista. Kista ini dilihat dengan mata telanjang berbentuk bulat-bulatan kecil berwarna kelabu kecoklatan dengan diameter sekitar 300 mikron (Farihah, 2008)

Pengujian terhadap kadar toksisitas ekstrak hewan dilakukan dengan mengamati tingkat kematian (mortalitas) yang ditimbulkan oleh ekstrak terhadap larva udang jenis $A$. salina Leach setelah dilakukan pengujian selama 24 jam. Batas aktivitas biologi adalah dengan nilai $\mathrm{LC}_{50}<$ $1000 \mu \mathrm{g} / \mathrm{mL}$ (Meyer et al,. 1982). Semakin kecil nilai $\mathrm{LC}_{50}$ yang dimiliki ekstrak hewan maka akan semakin toksik dan semakin berpotensi untuk memiliki aktivitas biologi/efek farmakologi.

Bioaktivitas hewan sangat dipengaruhi oleh kandungan senyawa kimia yang terdapat di dalamnya, sedangkan untuk mendapatkan senyawa kimia yang bersifat aktif tersebut dipengaruhi oleh metode pemisahan meliputi cara ekstraksi dan pelarut yang digunakan. (Albuntana dkk., 2011) dengan menggunakan pelarut nheksana, etil asetat dan air pada 4 jenis teripang Actinopyga miliaris, Bohadschia argus, Bohadschia marmorata, dan Holothuria leucospilota didapatkan $H$. leucospilota dalam fraksi air yang memiliki sifat toksisitas paling besar dengan nilai $\mathrm{LC}_{50}$ sebesar 50, $968 \mu \mathrm{g} / \mathrm{ml}$. Pada umumnya teripang yang termasuk dalam satu genus Holothuria mempunyai anatomi dan morfologi yang mirip sehingga diduga $H$. scabra juga memiliki nilai $\mathrm{LC}_{50}$ yang tinggi.

\section{METODE PENELITIAN}

\section{Pelaksanaan Penelitian}

Penelitian ini dilaksanakan pada bulan Oktober sampai dengan bulan Juni 2012 di Laboratorium Kimia, Jurusan Kimia UIN Malang dan Balai Penelitian Kacang-Kacangan dan Umbi-Umbian (BALITKABI).

\section{Alat dan Bahan Penelitian}

Alat yang digunakan adalah oven, timbangan analitik, seperangkat alat gelas, penyaring buchner, shaker, rotary evaporator, desikator, tabung reaksi, lampu $\mathrm{UV}$, vortex, aerator dan botol vial.

Bahan yang digunakan adalah teripang pasir (H.scabra) kering yang diperoleh dari pantai Kenjeran Surabaya dan larva udang A.salina sebagai hewan uji. Bahan kimia yang digunakan untuk pelarut adalah etanol dan n-heksana

\section{Prosedur Penelitian \\ Preparasi Sampel}

Sampel yang digunakan pada penelitian ini adalah teripang pasir kering yang didapatkan dari petani teripang pantai Kenjeran Surabaya. Teripang tersebut berwarna hitam dan teksturnya keras.

Sampel teripang kering ditumbuk menggunakan mortar sampai menjadi kecilkecil tujuannya untuk mempermudah proses penghalusan. Setelah ditumbuk, teripang dihaluskan menggunakan blender kemudian diayak menggunakan saringan teh.

\section{Analisis Kadar Air}

Teripang kering ditimbang sebanyak 5 g dan dimasukkan dalam cawan yang 
telah diketahui berat konstannya, selanjutnya dikeringkan didalam oven pada suhu 100-105 ${ }^{\circ} \mathrm{C}$ selama 1 jam. Sampel kering didinginkan dalam desikator dan ditimbang. Perlakuan ini diulangi sampai tercapai berat konstan.

\section{Ekstaksi Maserasi}

Serbuk teripang pasir ditimbang sebanyak $60 \mathrm{~g}$ dan dilarutkan dengan pelarut etanol sebanyak $300 \mathrm{~mL}$ selama 24 jam sambil dishaker selama 5 jam. Filtrat yang diperoleh disaring dan ampasnya dilarutkan lagi dengan pelarutnya. Perlakuan ini dilakukan sampai terjadi perubahan warna pada filtrat dari warna pekat menjadi tak berwarna (bening). Ketiga filtrat yang diperoleh selanjutnya digabung menjadi satu. Pada tahap ini dilakukan ekstraksi maserasi dengan perlakuan yang sama dengan menggunakan pelarut n-heksana.

Ekstrak etanol dan n-heksan yang diperoleh dipekatkan dengan rotary evaporator pada suhu $40{ }^{\circ} \mathrm{C}$ sampai diperoleh ekstrak pekat etanol dan nheksana.

\section{Uji Toksisitas dengan Larva Udang A.salina Leach}

\section{Penetasan Telur}

$250 \mathrm{~mL}$ air laut dimasukkan dalam botol penetasan, dimasukkan $2,5 \mathrm{mg}$ telur A.salina Leach. Selanjutnya diaerasi selama \pm 48 jam dan larva udang yang menetas siap digunakan untuk uji toksisitas.

\section{Uji Toksisitas}

Perlakuan uji toksisitas dilakukan sebanyak 3 kali ulangan pada masingmasing ekstrak sampel. Ekstrak kasar etanol dan n-heksana ditimbang sebanyak $100 \mathrm{mg}$ dan dilarutkan dengan menggunakan pelarutnya masing-masing sebanyak $10 \mathrm{~mL}$. Larutan yang diperoleh selanjutnya dipipet masing-masing sebanyak $500 \mu \mathrm{L}, 250 \mu \mathrm{L}, 100 \mu \mathrm{L}, 50 \mu \mathrm{L}$ dan $25 \mu \mathrm{L}$, kemudian dimasukkan ke dalam botol vial dan pelarutnya diuapkan hingga kering \pm 24 jam di dalam suhu ruang. Selanjutnya dimasukkan $100 \mu \mathrm{L}$ dimetil sulfoksida, setetes larutan ragi roti, $2 \mathrm{~mL}$ air laut, kemudian dikocok sampai ekstrak dapat larut dalam air laut dengan bantuan vortex. Larutan dipindahkan dalam labu ukur $10 \mathrm{~mL}$, kemudian dimasukkan 10 ekor larva udang A.salina dan ditambahkan air laut sampai volumenya menjadi $10 \mathrm{~mL}$, sehingga konsentrasinya masing-masing larutan menjadi 500, 250, 100, 50 dan 25 ppm. Kontrol digunakan sebagai pembanding yang dibuat dengan cara yang sama kecuali penambahan ekstrak. Pengamatan dilakukan selama 24 jam terhadap kematian larva udang.

Perhitungan $\mathrm{LC}_{50}$ dilakukan dengan menggunakan analisis probit menggunakan program MINITAB 14 dengan tingkat kepercayaan $95 \%$.

\section{Uji Senyawa Aktif dengan Uji reagen}

\section{Uji Flavonoid}

Ekstrak teripang pasir dimasukkan dalam tabung reaksi dan dilarutkan dalam 1-2 mL metanol panas $50 \%$. Kemudian ditambah logam $\mathrm{Mg}$ dan $0,5 \mathrm{~mL} \mathrm{HCl}$ pekat. Larutan berwarna merah atau jingga yang terbentuk, menunjukkan adanya flavonoid.

\section{Uji Alkaloid}

Ekstrak teripang pasir dimasukkan dalam tabung reaksi, ditambah $0,5 \mathrm{~mL} \mathrm{HCl}$ $2 \%$ dan larutan dibagi dalam dua tabung. Tabung I ditambahkan $0,5 \mathrm{~mL}$ reagen Dragendroff, tabung II ditambahkan $0,5 \mathrm{~mL}$ reagen Meyer. Jika tabung I terbentuk endapan jingga dan pada tabung II terbentuk endapan kekuning-kuningan, menunjukkan adanya alkaloid.

\section{Uji Triterpenoid/Steroid}

Ekstrak teripang pasir dimasukkan dalam tabung reaksi, dilarutkan dalam 0,5 $\mathrm{mL}$ kloroform, ditambah dengan $0,5 \mathrm{~mL}$ asam asetat anhidrat, kemudian ditambah dengan 1-2 $\mathrm{mL} \quad \mathrm{H}_{2} \mathrm{SO}_{4}$ pekat melalui dinding tabung tersebut. Jika hasil yang diperoleh berupa cincin kecoklatan atau 
violet pada perbatasan dua pelarut menunjukkan adanya triterpenoid, sedangkan jika terbentuk warna hijau kebiruan menunjukkan adanya steroid.

\section{Uji Senyawa Aktif dengan KLT}

Uji senyawa aktif dengan KLT dilakukan terhadap golongan senyawa yang positif dari hasil uji senyawa aktif dengan uji reagen dan memiliki nilai LC50 paling rendah berdasarkan uji toksisitas. Identifikasi dengan KLT digunakan plat silika gel $\mathrm{F}_{254}$ yang sudah diaktifkan dengan pemanasan dalam oven pada suhu $60-80{ }^{\circ} \mathrm{C}$ selama 30 menit. Masing-masing plat dengan ukuran $1 \times 10 \mathrm{~cm}^{2}$. Ekstrak teripang pasir ditotolkan sebanyah $1 \mathrm{~mL}$ pada jarak $\pm 1 \mathrm{~cm}$ dari tepi bawah plat dengan pipa kapiler. Noda/bercak hasil pemisahan kemudian diamati di bawah sinar UV pada panjang gelombang $254 \mathrm{~nm}$ dan $366 \mathrm{~nm}$.

\section{HASIL DAN PEMBAHASAN}

\section{Preparasi Sampel}

Teripang kering dihaluskan sampai menjadi serbuk. Tujuannya untuk memperbesar luas permukaan sehingga interaksi zat cairan ekstraksi semakin besar. Serbuk teripang yang sudah dihaluskan berwarna coklat kehitaman.

\section{Analisis Kadar Air}

Pada tahap ini sampel dimasukkan dalam cawan yang telah diketahui beratnya. Sampel dilakukan pemanasan pada suhu 100-105 ${ }^{\circ} \mathrm{C}$ selama 30 menit tujuannya untuk menguapkan air dalam sampel karena air akan menguap pada suhu $100{ }^{\circ} \mathrm{C}$, selanjutnya ditimbang dan perlakuan ini dilakukan berulang hingga beratnya konstan. Selisih berat sebelum dan sesudah pengeringan adalah banyaknya air yang diuapkan (Winarno, 2002). Dari hasil perhitungan diperoleh kadar air teripang kering sebesar $7,773 \%$.

\section{Ekstraksi Maserasi}

Proses perendaman dilakukan dalam waktu 24 jam dengan masing-masing pelarut sebanyak $300 \mathrm{~mL}$. Perendaman disertai pengadukan dengan shaker kecepatan 120 rpm selama 5 jam untuk mempercepat pelarutan senyawa kedalam pelarutnya dan memperbesar interaksi sampel dengan sampel. Hasil maserasi ditampilkan pada Tabel 1 .

Tabel 1 Hasil Maserasi Serbuk Teripang Pasir

\begin{tabular}{lll}
\hline Pelarut & $\begin{array}{l}\text { Warna } \\
\text { ekstrak } \\
\text { pekat }\end{array}$ & $\begin{array}{l}\text { Rendemen } \\
(\%)(\mathbf{b} / \mathbf{b})\end{array}$ \\
\hline Etanol & $\begin{array}{l}\text { Kuning ada } \\
\text { endapan }\end{array}$ & 6,13 \\
n-heksana & $\begin{array}{l}\text { Hitam } \\
\text { kecoklatan }\end{array}$ & 1,86 \\
\hline
\end{tabular}

Albuntana, dkk., (2011) dengan menggunakan pelarut $n$-heksana, etil asetat dan air pada empat jenis teripang didapatkan hasil ekstrak kasar teripang paling besar pada pelarut polar sebesar 95,6 $\%$. Senyawa metabolit sekunder di alam kebanyakan di dapat dalam bentuk gulanya sehingga larut dalam pelarut polar. Zhang, et al., (2006) menyatakan bahwa senyawaan yang dominan dihasilkan teripang berupa saponin yang apabila dihidrolisis akan menghasilkan suatu senyawa triterpenoid dan glikosida. Hasil ekstrak pekat masing-masing pelarut yang diperoleh selanjutnya digunakan untuk uji toksisitas.

\section{Uji Toksisitas dengan Larva Udang A.salina Leach}

Pada penelitian ini ekstrak kasar etanol dan n-heksana dilakukan uji toksisitas dengan menggunakan metode BSLT yaitu dengan melihat kematian dari larva udang setelah diberi perlakukan penambahan ekstrak dengan variasi konsentrasi dalam media hidupnya selama 24 jam.

Meyer, et al., (1982) menyatakan bahwa senyawa uji dikatakan toksik jika harga $\mathrm{LC}_{50}$ lebih kecil dari $1000 \mu \mathrm{g} / \mathrm{mL}$. Penentuan potensi bioaktif dilakukan dengan membandingkan nilai $\mathrm{LC}_{50}$ masing- 
masing ekstrak dengan ketentuan McLaughin (1991):

- $\mathrm{LC}_{50}<30$ ppm ekstrak berpotensi sebagai antikanker (sitotoksik)

- $\mathrm{LC}_{50}$ 30-200 ppm ekstrak berpotensi sebagai anti mikroba

- LC50 200-1000 ppm ekstrak berpotensi sebagai pestisida

Berdasarkan analisa data dengan program MINITAB dengan kepercayaan 95 $\%$ dapat dilihat di Gambar 1 dan 2 dari masing-masing ekstrak kasar teripang pasir dalam pelarut etanol dan n-heksana.

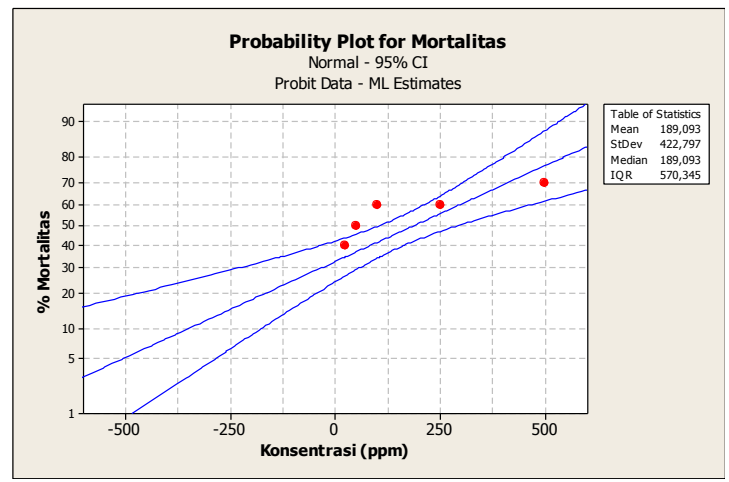

Gambar 1 Kurva Mortalitas Ekstrak Etanol

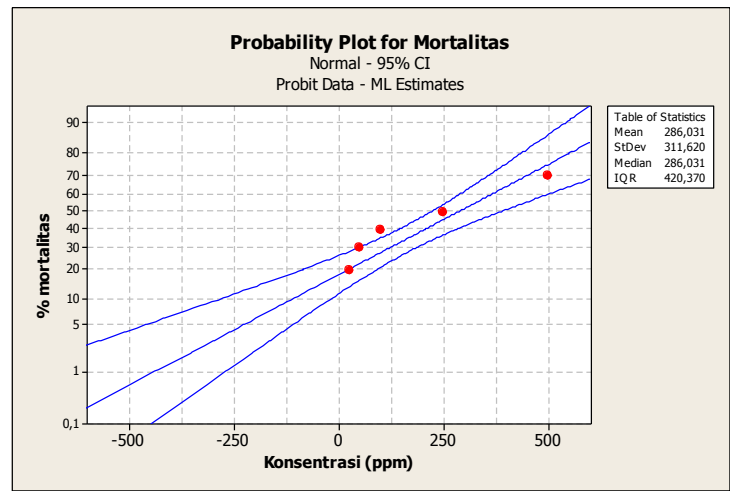

Gambar 2 Kurva Mortalitas Ekstrak n-Heksana

Berdasarkan hasil uji toksisitas didapatkan nilai $\mathrm{LC}_{50}$ masing-masing ekstrak pada Tabel 2.

Tabel 2 Hasil Uji Toksisitas Ekstrak Teripang

\begin{tabular}{lll}
\hline Ekstrak & LC $_{50}$ & Potensi \\
\hline etanol & 286,031 & Pestisida \\
n-heksana & 189,093 & Antimikroba \\
\hline
\end{tabular}

Dari nilai $\mathrm{LC}_{50}$ diketahui bahwa ekstrak n-heksana teripang bersifat lebih toksik sehingga dapat dimanfaatkan lebih lanjut dalam farmakologi.

\section{Kandungan Senyawa Aktif dalam Teripang pasir (H.scabra)}

Uji senyawa aktif dilakukan pada ekstrak yang memiliki nilai $\mathrm{LC}_{50}<1000$ ppm. Hasil identifikasi golongan senyawa aktif yang terdapat dalam ekstrak dapat dilihat pada Tabel 3.

Tabel 3 Hasil Pengamatan Uji Fitokimia

\begin{tabular}{lcc}
\hline $\begin{array}{l}\text { Golongan } \\
\text { senyawa }\end{array}$ & $\begin{array}{l}\text { Ekstrak } \\
\text { etanol }\end{array}$ & $\begin{array}{l}\text { Ekstrak } \\
\text { n-heksana }\end{array}$ \\
\hline Alkaloid, & & \\
meliputi : & & \\
Reagen & + & - \\
Dragendroff & & \\
Reagen Meyer & + & - \\
Flavonoid & - & - \\
\multicolumn{1}{c}{ Steroid } & + & ++ \\
\hline
\end{tabular}

Hasil identifikasi senyawa aktif berdasarkan uji fitokimia pada masingmasing ekstrak ditunjukkan adanya senyawa steroid dan alkaloid pada ekstrak etanol dan steroid pada ekstrak n-heksana.

\section{Flavonoid}

Menurut Robinson (1995), flavonoid akan menghasilkan senyawa kompleks yang berwarna merah atau jingga ketika direduksi dengan logam $\mathrm{Mg}$ dan $\mathrm{HCl}$ pekat. Uji flavonoid menunjukkan hasil yang negatif yaitu dengan tidak terbentuknya warna merah atau jingga pada masingmasing ekstrak ketika penambahan $\mathrm{Mg}$ dan $\mathrm{HCl}$ pekat.

\section{Alkaloid}

Pengujian alkaloid dengan menggunakan dua reagen yang berbeda yaitu Reagan Mayer dan reagen Dragendroff. Hasil pengujian menunjukkan ekstrak polar teripang mengandung senyawa alkaloid. 
Hasil positif pada uji Dragendroff ditandai dengan terbentuknya endapan jingga. Endapan tersebut diduga adalah kalium alkaloid. Pada pembuatan pereaksi Dragendroff bismuth nitrat dilarutkan dengan $\mathrm{HNO}_{3}$ pekat agar tidak terjadi reaksi hidrolisis karena garam-garam bismuth mudah terhidrolisis.

Hasil positif golongan alkaloid dengan reagen Mayer ditandai dengan terbentuknya endapan putih kekuningan. Pereaksi Mayer (kalium tetraiodomerkurat) paling banyak digunakan untuk mendeteksi golongan alkaloid karena pereaksi ini dapat mengendapkan hampir semua alkaloid (Robinson, 1995).

Rodriguez et al,. (2000) menyatakan kandungan senyawa yang terdapat pada teripang salah satunya adalah asam amino (aspartat, glutamat, histidin, treonin, alanin, arginin, prolin, tirosin, valin, serin, glisin, sistein, isoleusin, leusin, fenilalanin dan lisin), dengan demikian memperkuat adanya dugaan senyawa alkaloid yang terkandung dalam ekstrak teripang.

\section{Triterpenoid/Steroid}

Senyawa triterpenoid/steroid akan mengalami dehidrasi dengan penambahan asam kuat dan membentuk garam yang memberikan sejumlah reaksi warna. Uji steroid menunjukkan hasil yang positif pada kedua ekstrak yaitu ekstrak etanol dan nheksana, masing-masing terbentuk warna hijau kebiruan. Perubahan warna ini disebabkan adanya penambahan asam sulfat pekat pada dinding tabung reaksi. Menurut Robinson (1995), triterpenoid memberikan reaksi terbentuknya warna cincin kecoklatan ketika senyawa ini ditetesi asam sulfat pekat melalui dindingnya, sedangkan steroid akan menghasilkan warna hijau kebiruan.

Kustiariyah (2006) berhasil mengisolasi steroid dari teripang sebagai aprodisiaka alami dengan pelarut n-heksan, aseton, etil asetat dan metanol. Teripang pasir (H.scabra) juga mengandung steroid yang lebih tinggi $\left(58,46 \pm 2,94 \times 10^{-4}\right)$ dibandingkan teripang hitam (H.nobilis) dan teripang gamat (S.variegatus) dalam pemanfaatannya sebagai sumber steroid alami (Nurjannah, 2008).

\section{Pemisahan dengan KLT}

Uji senyawa aktif dengan kromatografi lapis tipis (KLT) dilakukan pada ekstrak yang memiliki nilai $\mathrm{LC}_{50}$ paling rendah yaitu ekstrak n-heksana dengan nilai $\mathrm{LC}_{50}$ sebesar 189,093 ppm. Larutan pengembang (eluen) yang digunakan yaitu n-heksana: etil asetat: amoniak (66:33:0,8). Fase diam yang digunakan yaitu silika gel $\mathrm{GF}_{254}$ yang diaktifasi pada suhu $80{ }^{\circ} \mathrm{C}$ selama 30 menit untuk menghilangkan air yang terdapat pada plat. Pengamatan dilakukan dibawah sinar UV dengan panjang gelombang 254 $\mathrm{nm}$ dan $356 \mathrm{~nm}$. Tabel 4 di bawah ini menampilkan hasil KLT senyawa steroid ekstrak n-heksan teripang pasir (H.scabra)

Tabel 4 Hasil KLT Ekstrak n-Heksana

\begin{tabular}{lll}
\hline Rf & \multicolumn{2}{c}{ Warna noda di bawah sinar UV } \\
\cline { 2 - 3 } $254 \mathrm{~nm}$ & \multicolumn{1}{c}{$356 \mathrm{~nm}$} \\
\hline 0,3 & Coklat & Tidak berwarna \\
\hline 0,54 & Coklat pudar & Tidak berwarna \\
\hline 0,72 & $\begin{array}{l}\text { Coklat } \\
\text { kehijauan }\end{array}$ & Tidak berwarna \\
\hline 0,78 & $\begin{array}{l}\text { Coklat } \\
\text { kehitaman }\end{array}$ & Tidak berwarna \\
\hline 0,44 & Tidak berwarna & $\begin{array}{l}\text { Biru muda } \\
\text { kehijauan }\end{array}$ \\
\hline
\end{tabular}

Pada tabel di atas menunjukkan terbentuknya 5 noda dengan $\mathrm{Rf}$ antara 0,30,78 . Noda-noda ini terpisah berdasarkan tingkat kepolarannya. Noda yang memiliki nilai Rf yang kecil 0,3 diduga cenderung bersifat polar dikarenakan noda tersebut lebih terdistribusi ke fase diam yang cenderung bersifat polar. Noda yang memiliki $\mathrm{Rf}$ yang tinggi 0,78 cenderung terdistribusi ke dalam fase gerak yang kepolarannya lebih kecil dibandingkan dengan fase diamnya.

\section{KESIMPULAN}

Masing-masing ekstrak teripang pasir (H.scabra) memiliki tingkat toksisitas 
terhadap larva udang A.salina Leach, ditunjukkan dengan nilai $\mathrm{LC}_{50}<1000$ ppm. Nilai keaktifan tertinggi diperoleh ekstrak n-heksana dengan nilai $\mathrm{LC}_{50}$ sebesar 189,093 ppm dan 286,031 ppm untuk ekstrak etanol.

\section{DAFTAR PUSTAKA}

Albuntana, Yasman, W., Wisnu. 2001. Uji Toksisitas Ekstrak Empat Jenis Teripang Suku Holothuridae Dari Pulau Penjaliran Timur, Kepulauan Seribu, Jakarta, Menggunakan Brine Shrimp Lethality Test (BSLT). Jakarta: Universitas Indonesia.

Cahyono, A. B. 2004. Keselamatan Kerja Bahan Kimia di Industri. Yogyakarta: UGM Press.

Colegate, S. M. dan Molyneux, R. J. 2007. Bioactive Natural Products: Determination, Isolation and Structural Determination Second Edition. Prancis: CRC Press.

Farihah. 2006. Uji Toksisitas Ekstrak Daun Ficus benjamina $L$ terhadap Artemia salina Leach dan Profil Kromatografi Lapis Tipis. Skripsi Diterbitkan. Surakarta: Fakultas Farmasi Universitas Muhammadiyah Surakarta.

Farouk A.E., Ghouse F.A.H., Ridzwan B.H , 2007. New Bacterial Species Isolated from Malaysian Sea Cucumbers with Optimized Secreted Antibacterial Activity. American Journal of Biochemistry and Biotechnology 3 (2): 60-65

Fieser, F.L. 1961. Advanced Organic chemistry, Reinhold Publishing Co. New York. hal 800-804.

Halimah, N. 2010. Uji Fitokimia dan Uji Toksisitas Ekstrak Tanaman AntingAnting (acalypha indica linn.) Terhadap Larva Udang Artemia Salina Leach. Skripsi Tidak Diterbitkan. Malang: Jurusan Kimia Fakultas Sains dan Teknologi, UIN. Kaswandi MA, Lian HH, Nurzakiah S, Ridzwan BH, Ujang S, Samsudin
MW, Jasnizat S and Ali AM. 2000. Crystal Saponin From Three Sea Cucumber Genus and Their Potential As Antibacterial Agents. 9th Scientific Conference Electron Microscopic Society. 12-14 Nov. 2000, Kota Bharu, Kelantan. 273276.

Kurnia, H.D. 2008. Kajian Ekstraksi Steroid Teripang Pasir (Holothuria scabra) Sebagai Sumber Testosteron. Bandung: Institut Pertanian Bogor.

Kustiariyah. 2006. Isolasi dan Uji Aktivitas Biologis Senyawa dari Teripang Pasir (Holothuria scabra) Sebagai Aproksida Alami. Thesis. Sekolah Pasca Sarjana. Bogor: Insitut Pertanian Bogor.

Lenny, S. Senyawa Flavonoida, Fenil Propanoida, dan Alkaloida. Sumut: USU Respository. http://library.usu.ac.id/download/fmi pa/06003488.pdf-senyawa. Tanggal akses 5 Mei 2010.

Matraga, V. 2005. Echinodermata; Progress In Molecular and Subcellular Biology Springer. Jerman

Martoyo J, Aji N dan Winanto Tj. 2000. Budidaya Teripang. Jakarta: Penebar Swadaya.

McLaughlin JL, Chang C-J, Smith DL. Bench top bioassays for the discovery of bioactive natural products An update. In: Atta-urRahman, ed. Studies in Natural Products Chemistry. Amsterdam: Elsevier; 1991;9:388-409.

Meyer, B.N., Ferrigni, Putnam, J.E. Jacobsen, L.B. Nichols, and McLaughlin. 1982. Brine Shrimp: A Convenient General Bioassay for Active Plant Constituents. Planta Medica 45: 31-34.

Nurjannah. 2008. Identifikasi Steroid Teripang Pasir (H.scabra) dan Pemanfaatannya sebagai sumber steroid alami. Disertasi. Sekolah Pasca Sarjana. Bogor: Insitut Pertanian Bogor. 
Reina, A. 2004. Sea Cucumber a Promosing Mainstay Commodity. Program $O G B \quad$ Indonesia. http://www.oxfamgb.org/eastasia [26 Februari 2005] diakses tanggal 19 Juni 2011.

Robinson. 1991. Kandungan Organik Tumbuhan Tinggi. Bandung: Institut Teknologi Bogor.

Rodriguez E., Gonzales M., Caride B., Lamas M.A., Taboada M.C., 2000. Nutritional Value of Holothuria Forskali Protein And Effects On Serum Lipid Profile In Rats. J. Physiol. Biochem. 58(1):39-44

Soemirat, J. 2005. Toksikologi Lingkungan. Gadjah Mada University Press, Yogyakarta
Sudarmadji, S., Haryono dan Suhardi. 2003. Analisa Bahan Makanan dan Pertanian. Yogyakarta: Liberty.

Wibowo, S. Yunizal.1997. Teknologi Penanganan dan Pengolahan Teripang (Holothuriadea). Jakarta: IPPL Slipi.

Winarno, F. G. 2002. Kimia Pangan dan Gizi. Jakarta: PT Gramedia Pustaka Utama.

Zhang, Y.., H.Y. Yi, and H.F. Tang. 2006. Cytotoxic Sulfated Triterpene Glycosides From The Sea Cucumber Pseudocolochirus Violaceus. Chemistry \& Biodiversity, hlm 807-817. 